\title{
Process Innovation Promoters, Firm Performance and Moderating Role of Service Quality Practices in SACCOs in Kenya
}

\author{
Leonard Omondi Otii \\ Department of Business and Economics \\ School of Business, Karatina University, Kenya \\ Postal Address: P.O. Box 298, Code 20200 \\ Kericho, Kenya \\ Kenneth Lawrence Wanjau (PhD) \\ Department of Business and Economics \\ School of Business, Karatina University, Kenya \\ Postal Address: P.O. Box 1957, Code 10101 \\ Karatina, Kenya \\ Humphrey Omondi (PhD) \\ Department of Business and Economics, School of Business \\ Karatina University, Kenya \\ Postal Address: P.O. Box 1957, Code 10101 \\ Karatina, Kenya
}

\begin{abstract}
The purpose of the study was to explore the relationship that exist between process innovation promoters and the performance of SACCOs in Kenya and the moderating effect of service quality practices. The primary data was collected from the Chief Executive Officers of the deposit taking SACCOs where a semi-structured questionnaire was administered. Data were analysed by employing Statistical Software for Social Sciences (SPSS) Version 22 and structural equation modelling using AMOS version 25. The hypotheses in this study were tested using structural equation modelling and hierarchical moderated multiple regression (MMR). Overall, the study found out that, Process innovation promoters have positive influence on performance of SACCOs in Kenya. The study also found out that, service quality practices $\left(R^{2}\right.$ change) is 0.115 implying that the moderating effect of service quality practices gained $11.5 \%$ variance in the SACCOs, above and beyond the variance by process innovation promoters and performance.The study recommends that, SACCO management together with their partners should deliberately nurture a customer relationship management culture that will enable them realize positive performance that has been influenced by service quality practices and again SACCOs need to invest in an effective innovation process that will enable more employees graduate as process innovation promoters who will purposely focus on how service quality practices can be part of the firm culture and hence improving on their performance.
\end{abstract}

Key Words: Process Innovation Promoters, Service Quality Practices, SACCOs, Performance

\subsection{Introduction}

Innovation is broadly seen as an essential component of competitiveness, embedded in the organizational structures, processes, products and services within a firm. Innovativeness is one of the fundamental instruments of growth strategies to enter new markets, to increase the existing market share and to provide the company with a competitive edge. Motivated by the increasing competition in global markets, companies have started to grasp the importance of innovation, since swiftly changing technologies and severe global competition rapidly erode the value added of existing products and services. Thus, innovations constitute an indispensable component of the corporate strategies for several reasons such as to apply more productive manufacturing processes, to perform better in the market, to seek positive reputation in customers' perception and as a result to gain sustainable competitive advantage (Gunday, Ulusoy, Kilic \& Alpkan 2011).

The implementation of a new or significantly improved production or delivery method is called a process innovation. This may include significant changes in techniques, equipment and/or software. In most cases, process innovations are 
intended to decrease unit costs of production or delivery, to increase quality, or to produce or deliver new or significantly improved products $(\mathrm{OECD}, 2005)$.

To enhance the organizational innovation in enterprises there are those who actively and intensively support the innovation process" in these enterprises called organizational innovation promoters. Promoters are those individuals who actively and enthusiastically promote innovations throughout the crucial organizational stages.

Process promoters actively arbitrate between the technical and economic world by means of organizational knowledge (Hauschildt, 2004). Since innovations not only affect the innovating department but also influence other departments in the organization, economic progress needs both the good will of the immediate participants and also the good will of the affected actors. Process promoters overcome administrative barriers by recognizing organizational hurdles (Hauschildt and Chakrabarti, 1988; Hauschildt and Kirchmann, 1997); Hauschildt and Schewe, 1997). The defining characteristics of the process promoter is his or her role in interfacing within the organizational structure, e.g., as project leader. Based on their negotiation skills, the process promoter mediates between those involved and affected parties (Hauschildt, 2004).

The process promoter derives his influence from organizational know-how and intra-organizational networks. He makes the connection between the power and the expert promoter and has the necessary diplomatic skills to bring together the people necessary for the innovation process and connect all the stakeholders involved in the operational processes. The process promoter helps to overcome bureaucratic and internal administrative barriers by means of his internal organizational networks (Gemünden, Salomo \& Hölzle, 2007).

Fogli (2006) defines service quality as “a global judgement or attitude relating to a particular service; the customer's overall impression of the relative inferiority or superiority of the organization and its services. Service quality is a cognitive judgement".

Service quality practices have become an essential part of organizational success due to increased customer expectations and customization of services in many markets. Good service quality used to mean that the output was made to conform to the specifications set by the process designers. Today, the concept of service quality is evolving to mean uniformity of the service output around an ideal (target) value determined by the customer. Accordingly, it is essential that service providers recognize customer perceptions and expectations in addition to the factors that influence their satisfaction with the service provided (Saghier, 2015).

In a competitive business environment, Service quality is an important differentiator and a driver of service-based businesses. Service quality is a major success factor in that it drives customer retention and market share, that is, the service provider's ability to capitalize on scale

\subsection{Statement of the problem}

The principal objective and the ultimate goal of any business enterprise is actually to learn and understand what actually goes on in their customers' minds. This is the essence of making an organizational decision on the necessary processes in order to get the customer satisfied. And by accomplishing the aforementioned, the business enterprises are expected to design standard operating procedures with the processes embedded in the procedures and the actual individuals who handle the processes so as to deliver the expectations of the customers. The expectations of the customers are that they need to get satisfied at the point of service delivery. Most of the financial institutions, Savings and Credit Cooperatives(SACCOs) in Kenya included do not satisfy their clients up to 100 per cent as per their expectations but they are able to reach 60 per cent(Kombo,2016). This is occasioned by the integration of the customers into the business processes which has not been realized (Simon \& Thomas, 2016). This leads to poor service provision that affects customer satisfaction and hence firm performance of SACCOs. A Savings and Credit Co-operative in Kenya will struggle to meet its performance targets due to disgruntled customers. It will also struggle retaining them since they will seek alternative financial institutions like Micro Financial Institutions (MFIs) who have incorporated service quality practices in their processes. This study sought to fill this research gap.

\subsection{Purpose of the study}

The objective of this study was to evaluate the Process Innovation Promoters-Service Quality practices-performance relationship, drawing on data collected from 158 SACCOs in Kenya. This study seeks to contribute to the Process Innovation promoter-performance literature by incorporating Service Quality practices as a moderator. More specifically, the first research question lies in: Is there Process innovation promoter-performance relationship and secondly, can the relationship between process innovation promoter and performance be moderated by service quality practices? 


\subsection{Literature Review}

\subsection{Theoretical Framework}

\subsubsection{Promoter Theory}

Promoter theory is based on the notion that the success of innovation processes depends on overpowering certain barriers, that is, it requires promoters who commit enthusiastically to specific innovation projects and help overcome those barriers. This theory presents a consistent explanatory framework for working with the construct of innovation barriers and provides the concept of power bases which are essential to overcoming innovation barriers (Hauschildt, 1999). Furthermore, the promoter model offers the possibility of describing the case of universal promoter which equates to the champions model as well as the chance to explain the division of labour between different types of specialized promoters. There is empirical proof for both the specialized and universal cases (Rost et al, 2007) but the former is especially relevant when it comes to complex technologies and finding system solution (Hauschildt,1999).

Promoter theory stresses that the different specialized promotor roles do not have to be played by different individuals, but can also be combined in one person, the 'universal promotor'. Promotor theory offers a consistent and elaborate base for describing and explaining the role of transformational leaders in innovation processes. Its conceptual focus on a single organization is, however, too limited in scope (Fichter, 2005).

\subsubsection{Collective Entrepreneurship Concept}

Collective entrepreneurship is a network organization that allows a diverse group of people to share the risks and the rewards associated with the discovery and exploitation of new business opportunities. Collective entrepreneurship has emerged as a viable strategy for producer enterprises to accrue economic benefits and improved market access. Producers' participation and collective action is the core of the value chain development. (Chagwiza, Muradian, Ruben \& Tessema, 2011).

\subsection{Empirical literature}

Sintset, Nekoumanesh and Yang (2013) in their study of Process Innovation and it impacts on organization's performance, discovered that the application of process innovation has a positive impact on the municipalities financial and customers performances. Also, the importance of process innovation as a step by step process and not a big bang change was discovered to be crucial for a successful process innovation. Applying corporate social responsibility as a self- regulation mechanism inside an organization, which contribute to environmental sustainability for organization also showed positive relation with municipalities' performance. In this study, the municipalities were investigated as enterprises.

In an attempt to increase understanding about the key persons (promoters) in project business organizations, the managers may do this by enhancing the communication flow by connecting the experts and the executives more efficiently. The findings by Ryynänen and Salminen (2014) indicate that during project sales there may be numerous process promoters with the dual roles of power and process promoter. In addition, this study demonstrated the appearance of process promoters in the project supplier's social network. The findings of the present study contribute to the literature on promoters by focusing especially on process promoters during project sales. The results of the present study suggest that the process promoters need to be identified and supported in order to build an effective cross-functional project sales team in project business.

The process promoter has the expertise of organizational know-how and network building. The process promoter derives his influence from organizational know-how and intra-organizational networks. He makes the connection between the power and the expert promoter and has the necessary diplomatic skills to bring together the people necessary for the innovation process and connect all the stakeholders involved in the operational processes. Process promoters actively arbitrate between the technical and economic world by means of organizational knowledge (Hauschildt, 2004).

Using extensive organizational knowledge, the process promoter takes responsibility in maintaining information relations between the other promoters and to other actors in the organization as well as in organizing e.g. the process flow, division of work, schedules and making sure that the innovation complies with the strategic planning of the organization as a whole (Hauschildt \& Chakrabarti, 1999). 
The role of process promoters is of particular interest, as they act as links between power and expert promoters. In particular, there appears to be a dearth of studies related to project sales, despite these phases having a substantial impact on the success of subsequent phases. By increasing understanding of the role of process promoters in the project sales process, managers may be able to better identify these key persons and make the changes needed to utilize them more effectively (e.g. by building project teams and supporting them, and by placing them in positions where they can link matrix structures more extensively). In practice, managers may enhance communication flow by connecting experts and executives more effectively. Obtaining the benefits of a matrix organization also requires an understanding of the key persons and the mechanisms connecting the organizational functions ((Koskinen, 2012) and these are the process innovation promoters.

In a study by Chin, Lo and Ramayah (2013) on "Market Orientation and Organizational Performance with the Service Quality as the moderator", it was interestingly established that Service Quality was found to have moderated the relationship between Market Orientation and performance of the hotels in Malaysia. Service Quality practices exists to fill in the gap between customers' expectations and their perception of the service providers' performance that further creates differentiation and competitive advantage, which enhance Market Orientation practices and ultimately lead to improvements in the firm's performance.

$\mathrm{He}$ and $\mathrm{Li}$ (2011) examined the moderating effect of service quality (SQ) on the "Effects of Corporate Social Responsibility (CSR) Association on Service Brand Performance" where a survey of customers of mobile telecommunications services was conducted. It was established that service quality practices have direct effects on brand identification and customer satisfaction and indirect effects on customer satisfaction (via brand identification) and on service brand loyalty (via customer satisfaction and via "brand identification/customer satisfaction").Second, SQ enhances the effect of CSR on brand identification.

Taouab and Issor (2019) suggest that the firm performance should be seen as an achievement or results obtained by management, economics, and marketing in providing competitiveness, efficiency, and effectiveness to the company. Performance measurement system (PMS) is a group of techniques developed by the organizations to evaluate the performance of business activities. According to the study by Folan and Browne (2005), performance measurement should involve employees in their development (particularly customer satisfaction measures); ensure that those measures used are relevant to managers and employees in performing their day-to-day jobs; be part of a feedback loop that links them to manager and employee performance appraisals and primarily use non-financial performance techniques.

Given the ever-increasing pressure on marketers to demonstrate the value of their activities to the firm, Khantimirov (2017) attempts to establish the role played by the market shares' contribution to profitability which leads to the establishment of performance. Market share reflects how marketing expenditures contribute to stakeholders' value. As a measure of marketing productivity, market share is also linked with the overall firm's profitability. It is also crucial to establish a positive link between profitability and non-financial marketing measures in order to maintain marketers' credibility and reinforce the importance of the marketing function within a firm. It is important to note that a participant in the industry must establish the strength of the competitors hence the market share.

Number of employees can also be used as performance measure. It is a non-financial performance measure. Employees are major assets of any organization. The active role they play towards a company's success cannot be underestimated. As a result, equipping these unique assets through effective training becomes imperative in order to maximize the job performance. Vosloban (2012) in his study on "The Influence of the Employee's Performance on the Company's Growth - A Managerial Perspective", established that motivated staff in their numbers can stimulate improved performance. It is well known that the companies which know how to use and invest in their resources can grow faster, making from this a business strategy on the emerging markets. This is mainly considered a managerial.

The services and products offered by the business enterprises is also a measure of performance. The availability of quite a good range of products in any business organization shows that the performance is likely to be enhanced due to the fact that these are sources of revenue streams.

\subsection{Conceptual Framework}

A conceptual framework is a structure which the researcher believes can best explain the natural progression of the phenomenon to be studied (Camp, 2001). It is linked with the concepts, empirical research and important theories used in promoting and systemizing the knowledge espoused by the researcher (Peshkin, 1993).

Conceptual framework is the researcher's own idea or proposition regarding the problem to be explored and its solution as specific direction. It is an organized way of thinking how and why a research or project takes place and how one 
understands its activity. It describes the overview of the researcher's thoughts, concepts or ideas of how a research plan is implemented. It gives complete direction to the study (Premkumar, 2018).

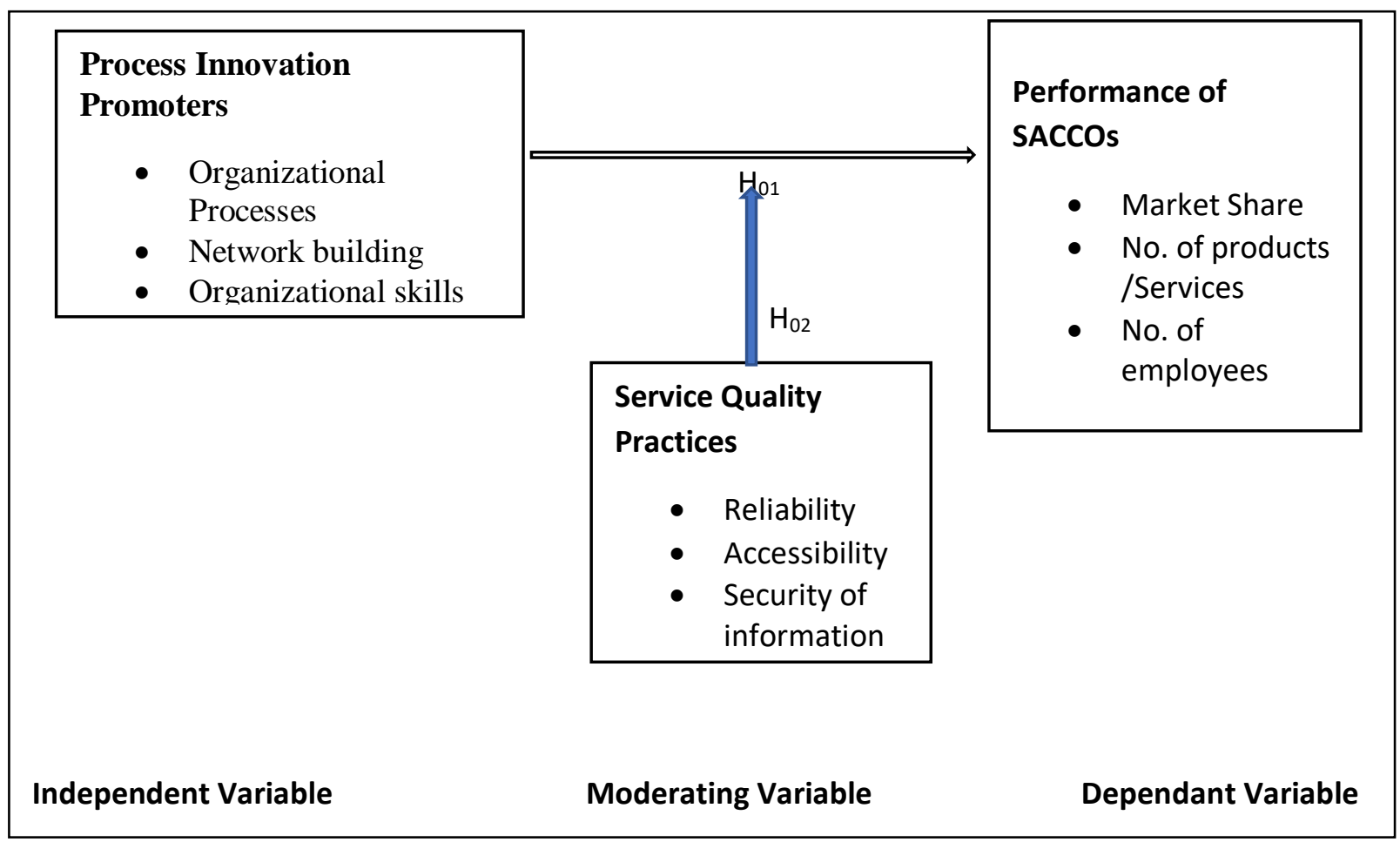

Figure 1: Conceptual Framework

\subsection{Methodology}

The study employed the use of cross-sectional survey design. The sampling frame for the study was Sacco Societies Regulatory Authority (SASRA) where census of 158 co-operatives was conducted. Israel (2012) posits that although cost considerations make census technique impossible for large populations, a census is attractive for small populations of 200 or less. The target population was the Savings and Credit Co-operative Societies (SACCOs) in Kenya which draw their membership from the salaried persons in employment and rural arrangements distributed across the Country in almost all Counties in Kenya. These were the Savings and Credit Co-operatives (SACCOs) that have been licensed to carry out deposit taking business by the licensing authority called Sacco Society Regulatory Authority (SASRA). The data was collected using a semi-structured questionnaire which was self- administered. The closed ended questions were on a 5-point Likert-scale (1 - "strongly agree" to 5 - "strongly disagree") that were used to measure respondents" agreement with the concepts that were under investigation. Likert scales are well known in attitude measurement, where they are used to ask subjects to evaluate a set of attitude statements using scales with common categories such as strongly agree, agree, neutral, disagree, and strongly disagree. The respondents were the Chief Executive Officers of the respective SACCOs.

Pilot study was carried in 18 SACCOs to test the effectiveness of the questionnaires such that in areas where weaknesses were realised, they were rectified. This was almost 10 per cent of the SACCOs which have been licenced by Sacco Societies Regulatory Authority (SASRA) to undertake deposit-taking business. The Cronbach Alpha ranged from 0.796 to 0.819 indicating the achievement of high reliability of the data as shown in table 1. Mertens (2010) avers that the closer the coefficient is to 1.0, the more reliable the measurements. This study adopted construct validity. Mertens advises that factor analysis can be used to validate hypothetical constructs as it attempts to cluster items or characteristics that seem to correlate highly with each other in defining a particular construct. 
Table 1: Process Reliability of the Constructs

\begin{tabular}{|l|l|}
\hline Constructs/Items & Cronbach Alpha \\
\hline Organizational Processes & 0.819 \\
\hline Network building & 0.796 \\
\hline Organizational Skills & 0.798 \\
\hline
\end{tabular}

Eigen values criterion was used to determine the selection of factor loadings for each component. Graham and Midgley (2000) says that the larger the Eigen value loading, the more important the associated principal component. In this case, the varimax with Kaiser Normalization sampling adequacy with Eigen value greater than 1 were used as the rotation method because the items were uncorrelated. Montgomery, Peck and Vining (2001) recommend that a minimum factor loading of 0.40 should be used when factor analysis is used to refine construct validity. All items had factor loadings ranging from 0.647 to 0.817 as shown in Table 2 .

Table 2: Factor Loadings

\begin{tabular}{|l|l|}
\hline Constructs/Items & Factor loadings \\
\hline Organizational Processes & 0.817 \\
\hline Network building & 0.779 \\
\hline Organizational Skills & 0.647 \\
\hline
\end{tabular}

In order to test the study hypothesis, structural equation modeling (SEM) was used with the aid of Amos version 25 software. A structural model was to test the simple relationship between Process Innovation Promoters and performance and the testing of hypotheses. The hypotheses in this study were tested using structural equation modeling and hierarchical moderated multiple regression (MMR).

\subsection{Data Analysis and Results}

\subsection{Descriptive Statistics}

To establish the level of process promoters, the study first sought to investigate whether the SACCOs have departments manned by Process innovation promoting individuals. The SACCOs ultimate goal of process promoters is to have service process that is acceptable, effective and efficient. The study determined, if the SACCOs have departments maned by individuals concerned with processing clients' requests. The results indicate that $94 \%$ of the SACCOs agreed implying that SACCOs attach considerable importance to the individuals involved in the SACCOs processes. Also, the study established that there is sequence of process flow in most SACCOS $(96.7 \%)$ as shown in the figure 2. Jointly, the results mean that SACCOs have key people who help to overcome bureaucratic and internal administrative barriers by means their internal organizational networks

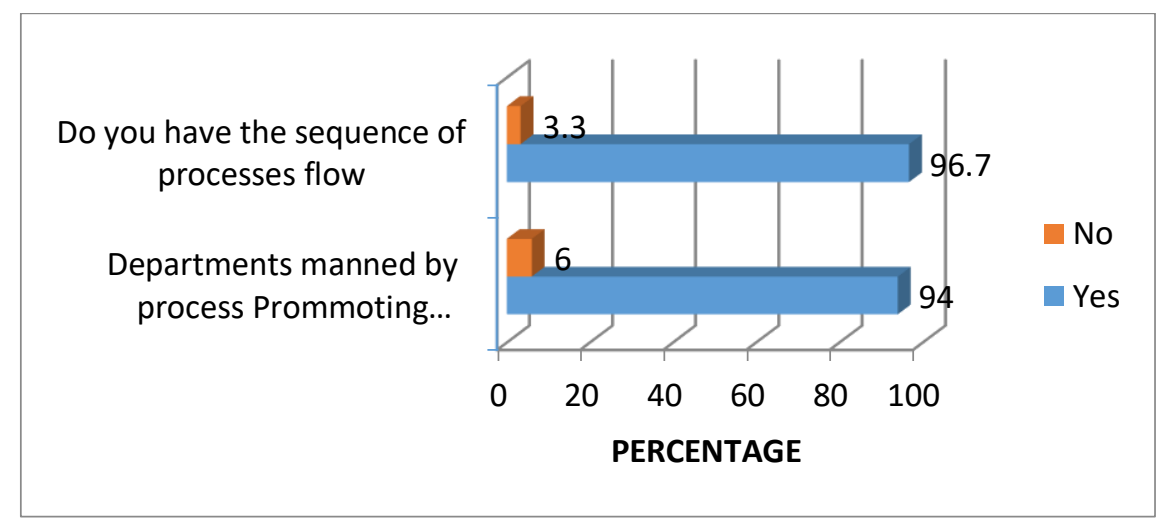

Figure 2: Process Promoters Contribution

\subsubsection{Organizational Processes Contribution}

Table 3 presents the percentage, mean and standard deviation results arising from the analysis of process innovation promoter data. The mean for the organizational process items ranged from a minimum of 1.040 to 1.980 which is an indication that the respondents agreed to the statements on organizational process. The standard deviations ranged from 0.227 to 0.617 implying moderate deviation of responses from the mean. The overall mean of organizational process is $1.576(\mathrm{SD}=1.297)$. On average, the respondents agreed to the statements regarding the presence of the organizational process promoter dimensions. Therefore, it is concluded that, SACCOs in Kenya value process promoters and therefore 
have in place policies and conditions necessary to enhance performance. The Deposit Taking Saccos (DTSs) in Kenya therefore seem to understand that Process promoters play key role in innovation-related communication process as they often connect stakeholders involved in the operational processes in the SACCO using their diplomatic skills to bring together the people necessary for the innovation process.

A study by Erkmen (2018) on how a business organization can build a brand equity is cultivated in services, establishes that the distinguished role of each mechanism is to build employee brand equity. That is, while internal communication enhances brand knowledge and role clarity, external communication and employee experience with the brand positively affect the brand commitment of employees hence the services rendered to the customers.

Table 3: Organizational Processes Factors

\begin{tabular}{|c|c|c|c|c|c|c|c|}
\hline Influence Decisions & 1 & 2 & 3 & 4 & 5 & Mean & $\begin{array}{l}\text { Std. } \\
\text { Deviation }\end{array}$ \\
\hline $\begin{array}{l}\text { Process promoter takes a central role in the innovation- } \\
\text { related communication process }\end{array}$ & $46.4 \%$ & $43 \%$ & $7.3 \%$ & $2 \%$ & $0.7 \%$ & 1.040 & 0.227 \\
\hline $\begin{array}{l}\text { Process promoter has the necessary diplomatic skills to } \\
\text { bring together the people necessary for the innovation } \\
\text { process }\end{array}$ & $37.1 \%$ & $55.6 \%$ & $6.6 \%$ & $0.7 \%$ & & 1.980 & 3.047 \\
\hline $\begin{array}{l}\text { Process promoter connects all the stakeholders involved } \\
\text { in the operational processes }\end{array}$ & $38.4 \%$ & $46.4 \%$ & $13.2 \%$ & $2 \%$ & & 1.709 & 0.617 \\
\hline Average mean score & & & & & & 1.576 & 1.297 \\
\hline
\end{tabular}

Key: $1=S A$ (Strongly Agree), $2=A$ (Agree), $3=N$ (Neutral), $4=D$ (Disagree), $5=S D$

\subsubsection{Network Building Contribution}

Table 4 shows that respondents were asked if the SACCOs have network building attributes and the results had the lowest mean score (Mean=1.788, $\mathrm{SD}=.745)$. The results show that the average mean for organizational network building had average mean score of 1.828 and standard deviation of .664. These mean values obtained on analysing process promoter data signifies that most SACCOs have in place recognizable network building individuals who actively links the technical and economic concerns in the SACCO and ensure the continued meaningful relations throughout the organization.

Table 4: Network Building Factors

\begin{tabular}{|c|c|c|c|c|c|c|c|}
\hline Influence Decisions & 1 & 2 & 3 & 4 & 5 & Mean & $\begin{array}{l}\text { Std. } \\
\text { Deviation }\end{array}$ \\
\hline $\begin{array}{l}\text { Process promoters actively arbitrate between the technical and } \\
\text { economic world by means of organizational knowledge }\end{array}$ & $27.8 \%$ & $62.3 \%$ & $9.9 \%$ & & & 1.788 & 0.745 \\
\hline $\begin{array}{l}\text { Using extensive organizational knowledge, the process promoter } \\
\text { takes responsibility in maintaining information relations between the } \\
\text { other promoters and to other actors in the organization as a whole }\end{array}$ & $27.8 \%$ & $57.6 \%$ & $13.9 \%$ & $0.7 \%$ & & 1.821 & 0.590 \\
\hline $\begin{array}{l}\text { Process promoter organizes the process flow, division of work, } \\
\text { schedules and making sure that the innovation complies with the } \\
\text { strategic planning of the organization }\end{array}$ & $39.7 \%$ & $43.7 \%$ & $13.9 \%$ & $2 \%$ & $0.7 \%$ & 1.874 & 0.656 \\
\hline Average mean score & & & & & & 1.828 & 0.664 \\
\hline
\end{tabular}

Key: $1=S A$ (Strongly Agree), $2=A$ (Agree), $3=N$ (Neutral), $4=D$ (Disagree), $5=S D$

\subsubsection{Organizational Skills Contribution}

The study sought to establish how the organization skills contributes to the performance of the SACCOs. Table 5 shows findings that respondents were asked if the SACCOs have organization skills and the results had the lowest mean score (Mean=1.782, SD=.701).

The results show that the average mean for organizational skills had average mean score of 1.874 and standard deviation of .890. This depicts strong agreement as far as the statements on the construct as concerned across the SACCOs surveyed. 
Sembiring (2016) avers that knowledge and skills of human resources have significant and simultaneous effect on the performance of SMEs. It was also found that the knowledge and skills of human resources have a partial significant influence on the performance of SMEs. Human Resource skills factor has greater impact on the performance of SMEs as compared to human resource knowledge factor.

Table 5: Organizational Skills Factors

\begin{tabular}{|l|l|l|l|l|l|l|l|}
\hline Influence Decisions & $\mathbf{1}$ & $\mathbf{2}$ & $\mathbf{3}$ & $\mathbf{4}$ & $\mathbf{5}$ & Mean & $\begin{array}{l}\text { Std. } \\
\text { Deviation }\end{array}$ \\
\hline $\begin{array}{l}\text { Process promoter distributes and } \\
\text { coordinates the activities relevant for } \\
\text { the innovation. }\end{array}$ & $37.1 \%$ & $47.7 \%$ & $9.3 \%$ & $5.3 \%$ & $0.7 \%$ & $\mathbf{1 . 8 4 8}$ & $\mathbf{1 . 1 2 4}$ \\
\hline $\begin{array}{l}\text { Process promoter ensures that } \\
\text { agreements between the participants } \\
\text { are kept. }\end{array}$ & $25.2 \%$ & $60.3 \%$ & $9.3 \%$ & 4.6 & $0.7 \%$ & $\mathbf{1 . 8 8 7}$ & $\mathbf{1 . 0 9 9}$ \\
\hline $\begin{array}{l}\text { Process Promoter co-ordinates } \\
\text { meetings of the participants. }\end{array}$ & $36.4 \%$ & $50.3 \%$ & $11.9 \%$ & $1.3 \%$ & & $\mathbf{1 . 9 5 4}$ & $\mathbf{0 . 7 6 9}$ \\
\hline $\begin{array}{l}\text { Process promoter ensures that } \\
\text { milestones and deadlines are kept. }\end{array}$ & $28.5 \%$ & $58.3 \%$ & $7.9 \%$ & $5.3 \%$ & & $\mathbf{1 . 7 8 2}$ & $\mathbf{0 . 7 0 1}$ \\
\hline $\begin{array}{l}\text { Process promoter moderates co- } \\
\text { operation of the participants in } \\
\text { difficult phases }\end{array}$ & $39.1 \%$ & $52.3 \%$ & $6.6 \%$ & $2 \%$ & & $\mathbf{1 . 9 0 1}$ & $\mathbf{0 . 7 5 5}$ \\
\hline Average mean score & & & & & & $\mathbf{1 . 8 7 4}$ & $\mathbf{0 . 8 9 0}$ \\
\hline
\end{tabular}

Key: $1=S A$ (Strongly Agree), $2=A$ (Agree), $3=N$ (Neutral), $4=D$ (Disagree), $5=S D$

\subsection{Hypotheses testing}

The objective of the study was to establish the extent to which the process innovation promoters contribute to the performance of savings and credit cooperatives societies.

In order to assess whether the model provided adequate fit for the data, the study considered both absolute fit indices and incremental fit indices (Hair et al., 2010). For absolute fit indices the study used root mean square error of approximation (RMSEA), goodness of fit index (GFI) and adjusted goodness of fit index (AGFI) (Hair et al., 2010). For incremental fit indices, Comparative Ft Index was used (Hair et al., 2010). These fit indexes were used to verify that the model was adequate (Browne \& Cudeck, 2003).

RMSEA values range from 0 to 1 with a smaller RMSEA value indicating better model fit (Marsh, et al., 2011). Good model fit is typically indicated by an RMSEA value of 0.05 or less (Hu \& Bentler, 1999), but a value of 0.08 or less is often considered acceptable (Browne \& Cudeck, 2003). RMSEA value of less than 0.05 is considered excellent, 0.05 to 0.08 is good while 0.08 to 0.10 is acceptable (Hu \& Bentler, 1999). Table 6 shows RMSEA results of 0.048 . This shows an acceptable model fit.

The goodness of fit index (GFI) is a measure of fit between the hypothesized model and the observed covariance matrix (McDonald \& Ho, 2002). The adjusted goodness of fit index (AGFI) corrects the GFI, which is affected by the number of indicators of each latent variable (McDonald \& Ho, 2002).

The GFI, AGFI and CFI fit indexes should be greater or equal to 0.8 (McDonald \& Ho, 2002). Table 6 shows GFI of .913 , AGFI of .852 and CFI index of .944 generally indicating acceptable model fit.

The hypothesized Model fitted the data adequately well as indicated by the fit statistics in table 6, that is, all the selected fit indices are within the cut-off points. This suggests that the hypothesized model adequately fitted with the data and therefore it is appropriate in testing the relationship between process promoters and performance of SACCOs. 
Table 6: GFI, AGFI, and CFI Model Fit Statistics Results

\begin{tabular}{lccccc}
\hline Indices & NFI & GFI & AGFI & CFI & RMSEA \\
& & & & & \\
\hline Model indices & .977 & .913 & .852 & .944 & .048 \\
Cut off & $>.900$ & $>.900$ & $>.800$ & $>.900$ & $<.080$ \\
& & & & & \\
\hline
\end{tabular}

The structural Equation Modeling (SEM) path diagram for this objective is shown in figure 3. Path coefficients were used to determine the direction and strength of the factor. The figure shows a path coefficient beta value of 0.600 ( $\beta=$ .600).This implies that for every unit improvement in the levels of Process innovation promoter, performance of SACCOs is predicted to increase by 0.600 units.

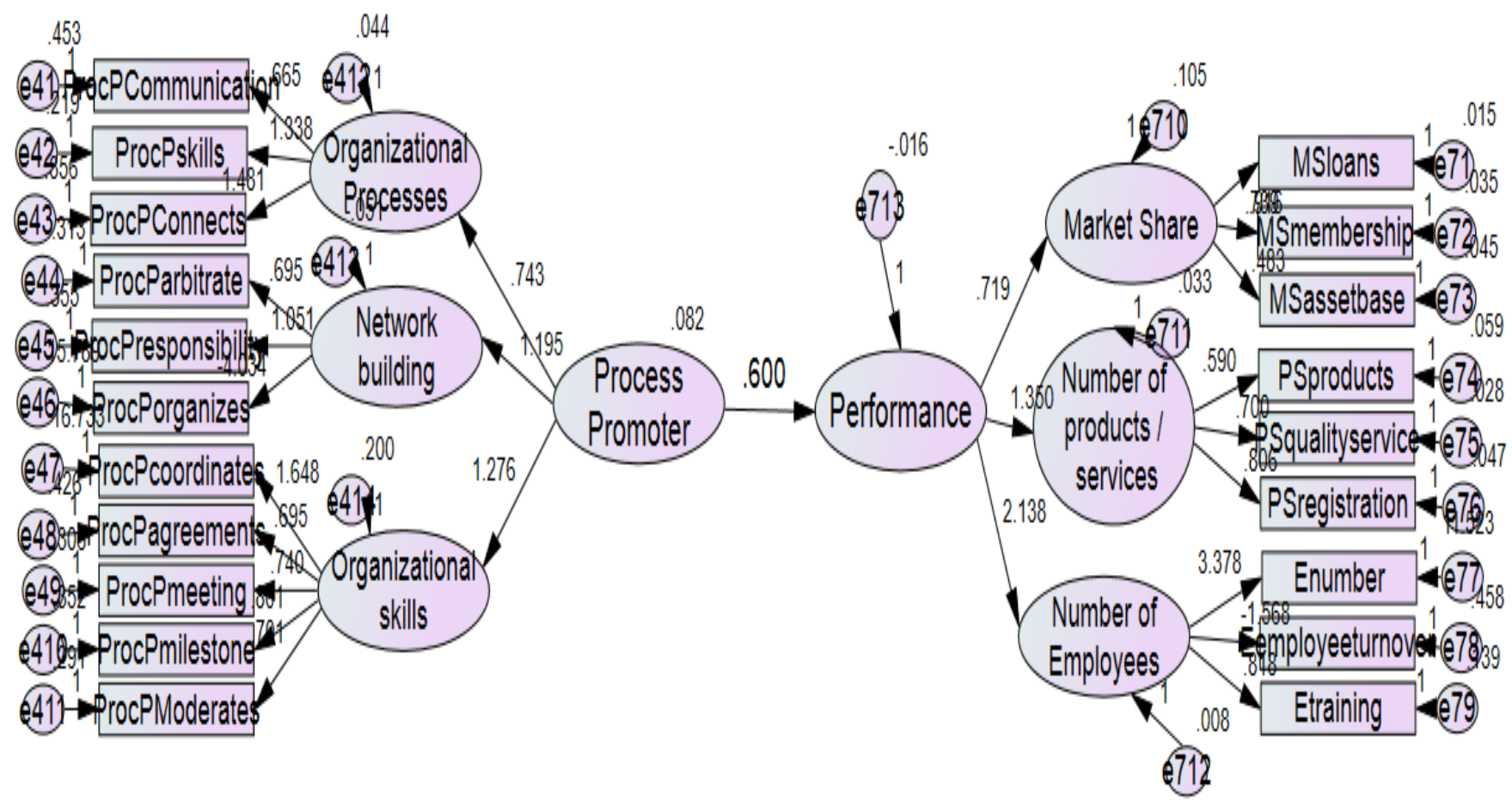

Figure 3: SEM path diagram for Process Innovation Promoters on Performance of SACCOs

Table 7 shows the regression weights of the model with their relative critical ratios to test the significance of each estimate. The critical ratios are Z-scores based on maximum likelihood estimation. The results show that, the coefficient estimate of Process Innovation Promoters $(\beta=0.600$, C.R. $=2.321, \mathrm{p}=000)$ is significant at $5 \%$ level of significance. The critical ratio is greater than the 1.96 standard normal distribution Z-score at $5 \%$ level of significance. The results thus show that a unit increase in Process innovation promoters is associated with an increase in performance by 0.600 units. The model generated is given by the equation below.

$Y=0.600 X+\varepsilon$

Where;

$Y$ is the performance of Saccos, $X$ is the levels of Process promoters, $\varepsilon$ is the error term 
Table 7: Regression Weights; Process innovation promoters on performance

\begin{tabular}{|c|c|c|c|c|c|c|}
\hline & & & Estimate & S.E. & C.R. & $\mathbf{P}$ \\
\hline Performance & $\begin{array}{l}<-- \\
\end{array}$ & Process Promoter & .600 & .259 & 2.321 & .000 \\
\hline Market share & $<---$ & Performance & .719 & & & \\
\hline No. of Products \& S & $<---$ & Performance & 1.350 & .400 & 3.378 & $* * *$ \\
\hline No. of Employees & $<---$ & Performance & 2.138 & .626 & 3.412 & $* * *$ \\
\hline Organizational Processes & $<---$ & Process Promoter & .743 & & & \\
\hline Network Building & $<---$ & Process Promoter & 1.195 & .446 & 2.678 & .007 \\
\hline Organizational skills & $<---$ & Process Promoter & 1.276 & .491 & 2.599 & .009 \\
\hline MS-asset base & $<---$ & Market share & .483 & .066 & 7.361 & $* * *$ \\
\hline MS-loans & $<---$ & Market share & .916 & & & \\
\hline PS-registration & $<---$ & No. of Products \& S & .806 & & & \\
\hline PS-quality service & $<---$ & No. of Products \& S & .700 & .103 & 6.807 & $* * *$ \\
\hline PS-products & $<---$ & No. of Products \& S & .590 & .114 & 5.186 & $* * *$ \\
\hline E-training & $<---$ & No. of Employees & .818 & & & \\
\hline E-employee turnover & $<---$ & No. of Employees & -1.568 & .264 & -5.934 & $* * *$ \\
\hline E-number & $<---$ & No. of Employees & 3.378 & .978 & 3.455 & $* * *$ \\
\hline ProcP-Communication & $<---$ & Organizational Processes & .665 & & & \\
\hline ProcP-skills & $<--$ & Organizational Processes & 1.338 & .463 & 2.889 & .004 \\
\hline ProcP-Connects & $<---$ & Organizational Processes & 1.481 & .520 & 2.850 & .004 \\
\hline ProcP-arbitrate & $<---$ & Network Building & .695 & & & \\
\hline ProcP-responsibility & $<---$ & Network Building & 1.051 & .221 & 4.766 & $* * *$ \\
\hline ProcP-organizes & $<---$ & Network Building & -4.034 & 1.044 & -3.864 & $* * *$ \\
\hline ProcP-coordinates & $<---$ & Organizational skills & 1.648 & .716 & 2.303 & .021 \\
\hline ProcP-agreements & $<---$ & Organizational skills & .695 & & & \\
\hline ProcP-meeting & $<---$ & Organizational skills & .740 & .151 & 4.888 & $* * *$ \\
\hline MS-membership & $<---$ & Market share & .739 & .080 & 9.274 & $* * *$ \\
\hline ProcP-milestone & $<---$ & Organizational skills & .801 & .163 & 4.903 & $* * *$ \\
\hline ProcP-Moderates & $<---$ & Organizational skills & .701 & .145 & 4.839 & $* * *$ \\
\hline
\end{tabular}

The results of this model were used to test the hypothesis of the study and conclude on the objective.

\section{$H_{01}$ Process innovation promoters do not have significant effect on performance of savings and credit cooperatives}

The critical ratio of the coefficient estimate of Process Innovation Promoters in the model was found to be greater than the standard normal distribution $\mathrm{Z}$-score at $5 \%$ level of significance $(/ \mathrm{CR} /=2.321>1.96)$. The null hypothesis was thus rejected and a conclusion drawn that, Process Innovation Promoters have a significant effect on performance of savings and credit cooperative societies.

The results indicate that the role played by the loans officers, registry clerks and credit managers is important for the success of these co-operative institutions.

\subsection{Moderating effect of Service Quality Practices on the relationship between Process Promoters and performance of cooperative societies}

A moderated multiple regression (MMR) analysis was fitted with process promoter as the only independent variable to test for the moderation effect of Service Quality Practices(SQP) in the relationship between process innovation promoters and the performance of cooperative societies. The results in table 8 show that model 1 has an R-square of 0.571 which implies that $57.1 \%$ of the variance in performance of the SACCOs is explained by the variations in Process Innovation Promoters as the only predictor in model 1. The R-square change in model 2 had a p-value less than 0.05 and subsequently, the R-square change in model 3 due to the simultaneous introduction of all the interactions term was 0.115 . The R-square change was attributed to a significant $\mathrm{F}$-change $\left(\mathrm{F}_{(1,147)}=58.855, \mathrm{p}=.000\right)$. The $\mathrm{p}$-value of the change was less than 0.05 thus it was considered significant at $5 \%$ level of significance. The significance of the change in R-square is attributed to a significant moderating effect of Service quality practices on the relationship between Process Innovation Promoters and performance of SACCOs in Kenya. 
Table 8: Model Summary for Process Innovation Promoters, Service Quality Practices and performance

\begin{tabular}{|c|c|c|c|c|c|c|c|c|c|}
\hline \multirow[b]{3}{*}{ Model } & \multirow[b]{3}{*}{$\mathbf{R}$} & \multirow{3}{*}{$\begin{array}{l}\text { R } \\
\text { Square }\end{array}$} & \multirow{3}{*}{$\begin{array}{l}\text { Adjusted } \\
\text { R Square }\end{array}$} & \multirow{3}{*}{$\begin{array}{l}\text { Std. } \\
\text { Error of } \\
\text { Estimate }\end{array}$} & \multicolumn{5}{|c|}{ Change Statistics } \\
\hline & & & & & $\begin{array}{ll}\mathbf{R} & \text { Square } \\
\end{array}$ & $\mathbf{F}$ & & & $\begin{array}{ll}\text { Sig. } & \text { F }\end{array}$ \\
\hline & & & & & Change & Change & df1 & df2 & Change \\
\hline 1 & $.756 a$ & .571 & .568 & .657 & .571 & 198.563 & 1 & 149 & .000 \\
\hline 2 & $.774 b$ & .600 & .594 & .637 & .028 & 10.423 & 1 & 148 & .002 \\
\hline 3 & $.845 c$ & .714 & .708 & .540 & .115 & 58.855 & 1 & 147 & .000 \\
\hline
\end{tabular}

a. Predictors: (Constant), Process promoters (X4)

b. Predictors: (Constant), Process promoters (X4), Service quality practices (Z)

c. Predictors: (Constant), Process promoters (X4), Service quality practices (Z), X4_Z

The SEM for assessing the moderating effect of Service Quality Practices on the relationship between Process Innovation Promoters and performance fitted the data adequately well as indicated by the fit statistics in table 9 . All the selected fit indices are within the cut-off points or threshold. This suggests that the model adequately fitted with the data and therefore it is appropriate in testing the relationship between Process Innovation Promoters and performance of SACCOs.

Table 9: Model fit indices for Process Innovation Promoters, Service Quality Practices and Performance of SACCOs.

\begin{tabular}{llllll}
\hline Indices & NFI & GFI & AGFI & CFI & RMSEA \\
\hline Model indices & .977 & .913 & .852 & .944 & .048 \\
Cut off & $>.900$ & $>.900$ & $>.800$ & $>.900$ & $<.080$
\end{tabular}

The structural Equation Model (SEM) for this moderated model is depicted by the path diagram in figure 4.The path diagram also explains the influence (contribution) of Process Innovation Promoters and Service Quality Practices on performance. The figure also explains the effect of the interaction term between the two on performance. It shows that, the path coefficient from interaction term on performance to be $0.082(\beta=0.082)$.

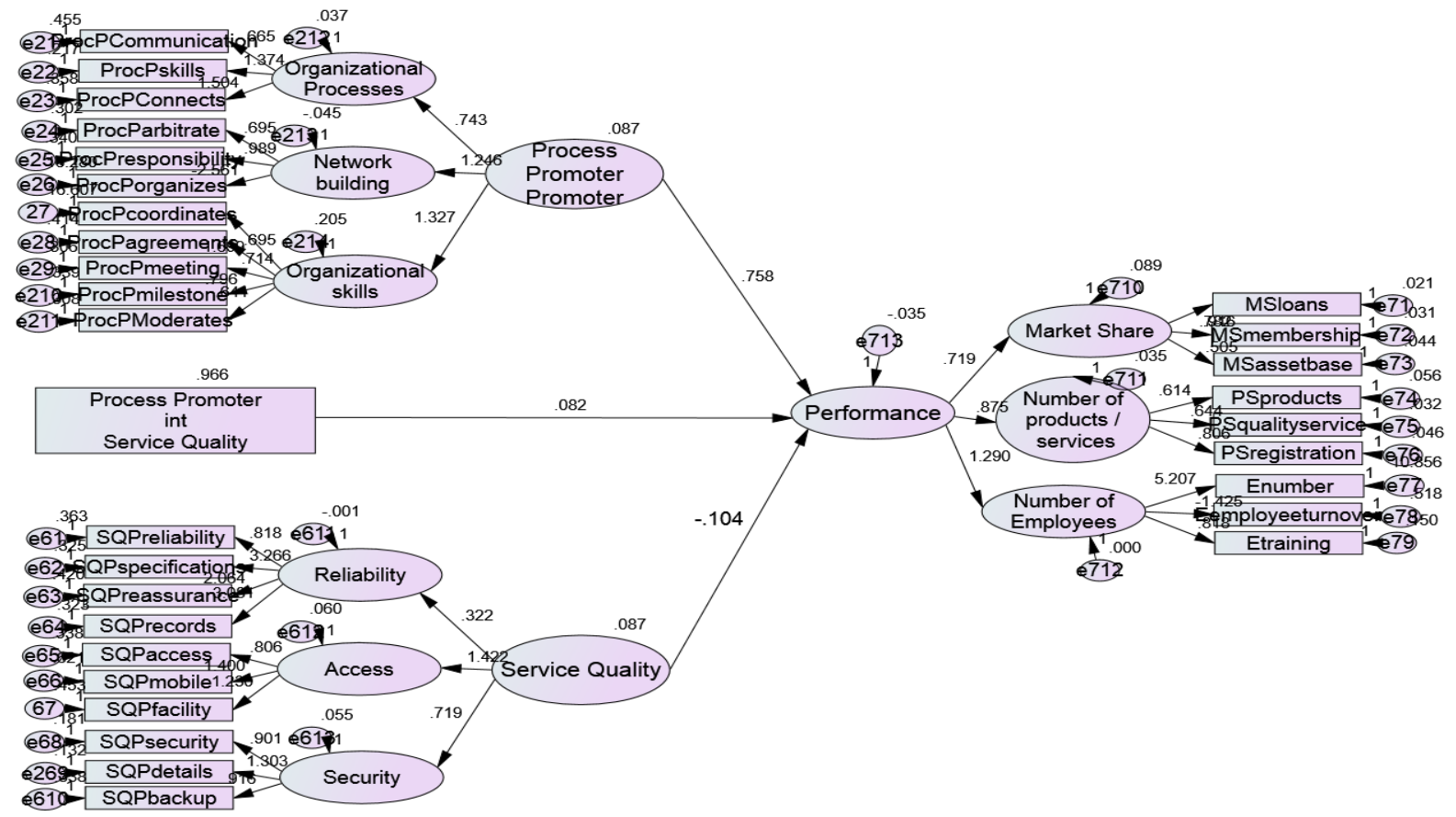

Figure 4: Moderated SEM path diagram for Process Innovation Promoters, Service Quality Practices and Performance

Table 10 is a statistical analysis of the estimated regression weights with critical ratios to assess the significance of the estimates. The critical ratios were used to test the significance of the coefficient estimates. The results of this SEM model support the results from the MMR model as it also revealed a significant moderating effect due to the introduction of the 
interaction term. Both Process Innovation Promoters $(\beta=0.758, /$ C.R. $/=2.641, \mathrm{p}=0.008)$ and Service Quality Practices $(\beta=-0.104, /$ C.R. $/=2.150, \mathrm{p}=0.032)$ have significant regression weights as shown by the critical ratios above 1.96 . The regression weight of the interaction between Service Quality Practices and Process Innovation Promoters $(\beta=0.082$, C.R. $=5.181, \mathrm{p}=* * *)$ also had a critical ratio greater than the 1.96 standard normal Z-score. This implied that Service Quality Practices significantly moderates the relationship between Process Innovation Promoters and Performance of SACCOs. This means that with the adherence to service quality practices, the performance of SACCOs in Kenya is likely to improve. The integration of Service Quality Practices as part of the entrepreneurial culture in SACCOs is a sure way of ensuring positive performance.

Table 10: Moderated Regression Weights for the SEM on Process Innovation Promoters, Service Quality Practices and Performance of SACCOs.

\begin{tabular}{|c|c|c|c|c|c|c|}
\hline & & & Estimate & S.E. & C.R. & $\mathbf{P}$ \\
\hline Performance & $\begin{array}{ll}<-- \\
--\end{array}$ & Service Quality & -.104 & .048 & -2.150 & .032 \\
\hline Performance & $<--$ & Process Promoter & .758 & .287 & 2.641 & .008 \\
\hline Performance & $<---$ & X4_Z & .082 & .016 & 5.181 & $* * *$ \\
\hline MS & $<---$ & Performance & .719 & & & \\
\hline PS & $<---$ & Performance & .875 & .191 & 4.572 & $* * *$ \\
\hline NoE & $<--$ & Performance & 1.290 & .286 & 4.513 & $* * *$ \\
\hline Reliability & $<---$ & Service Quality & .322 & .267 & 1.206 & .228 \\
\hline Access & $<---$ & Service Quality & 1.422 & .474 & 3.002 & .003 \\
\hline Security & $<---$ & Service Quality & .719 & & & \\
\hline Organizational Processes & $<--$ & Process Promoter & .743 & & & \\
\hline Network building & $<--$ & Process Promoter & 1.246 & .459 & 2.713 & .007 \\
\hline Organizational skills & $<---$ & Process Promoter & 1.327 & .503 & 2.636 & .008 \\
\hline SQPreliability & $<---$ & Reliability & .818 & & & \\
\hline SQPspecifications & $<---$ & Reliability & 3.266 & 2.630 & 1.242 & .214 \\
\hline SQPreassurance & $<---$ & Reliability & 2.064 & 1.756 & 1.175 & .240 \\
\hline SQPaccess & $<---$ & Access & .806 & & & \\
\hline SQPmobile & $<---$ & Access & 1.400 & .278 & 5.034 & $* * *$ \\
\hline SQPsecurity & $<---$ & Security & .901 & .232 & 3.888 & $* * *$ \\
\hline SQPdetails & $<---$ & Security & 1.303 & .327 & 3.980 & $* * *$ \\
\hline MSassetbase & $<---$ & MS & .505 & .067 & 7.516 & $* * *$ \\
\hline MSloans & $<---$ & MS & .916 & & & \\
\hline PSregistration & $<---$ & PS & .806 & & & \\
\hline PSqualityservice & $<---$ & PS & .644 & .102 & 6.334 & $* * *$ \\
\hline PSproducts & $<---$ & PS & .614 & .117 & 5.244 & $* * *$ \\
\hline Etraining & $<---$ & NoE & .818 & & & \\
\hline Eemployeeturnover & $<--$ & NoE & -1.425 & .284 & -5.011 & $* * *$ \\
\hline Enumber & $<--$ & NoE & 5.207 & 1.160 & 4.489 & $* * *$ \\
\hline MSmembership & $<---$ & MS & .782 & .079 & 9.966 & $* * *$ \\
\hline SQPbackup & $<---$ & Security & .916 & & & \\
\hline SQPfacility & $<--$ & Access & 1.230 & .243 & 5.062 & $* * *$ \\
\hline ProcPCommunication & $<--$ & Organizational Processes & .665 & & & \\
\hline ProcPskills & $<---$ & Organizational_Processes & 1.374 & .475 & 2.894 & .004 \\
\hline ProcPConnects & $<---$ & Organizational_Processes & 1.504 & .528 & 2.849 & .004 \\
\hline ProcPorganizes & $<---$ & Network_building & -2.561 & .868 & -2.949 & .003 \\
\hline ProcPmeeting & $<--$ & Organizational_skills & .714 & .141 & 5.053 & $* * *$ \\
\hline ProcPmilestone & $<--$ & Organizational skills & .796 & .155 & 5.150 & $* * *$ \\
\hline ProcPModerates & $<---$ & Organizational_skills & .641 & .132 & 4.848 & $* * *$ \\
\hline SQPrecords & $<--$ & Reliability & 3.081 & 2.488 & 1.238 & .216 \\
\hline ProcParbitrate & $<---$ & Network building & .695 & & & \\
\hline ProcPresponsibility & $<--$ & Networkbuilding & .989 & .199 & 4.980 & $* * *$ \\
\hline ProcPcoordinates & $<--$ & Organizational skills & 1.699 & .688 & 2.471 & .013 \\
\hline ProcPagreements & $<--$ & Organizational skills & .695 & & & \\
\hline
\end{tabular}

\section{Discussions, Conclusions and Recommendations}

The results of the moderation findings have significant implication to the management of SACCO's performance intentions. In the SACCOs that exercise high service quality practices, the performance is high. However, there is no performance differential in between SACCOs that have faster and SACCOs that have slow Process Innovation Promoters. The SACCOs with slow processes need to invest in service quality as a strategy to ensure SACCOs perform much better and to the satisfaction of the customers, therefore, in the presence of fast Process Innovation Promoters, Service Quality 
Practices becomes a significant success factor for SACCOs' growth intentions in Kenya. In order to gain competitive advantage, the results further indicate that the SACCOs that have slow Process Innovation Promoters need to invest in other success factors like expertise promoters as one success factor management can adopt to enhance performance for the slow process promoters.

A Study by Gemünden, Salomo and Hölzle (2007) found out that the Process Innovation Promoter derives his/her influence from organizational know-how and intra-organizational networks. He/she makes the connection between the power and the expert promoter and has the necessary diplomatic skills to bring together the people necessary for the innovation process. This therefore means that the Process Innovation Promoter has to be the one facilitating interaction and not merely the one that is ensuring a formal process is followed in accordance with the predefined milestones and procedures in place (Goduscheit, 2014).

Parasuraman, Zeithaml and Berry (1994) found that reliability means organizations perform a service correctly the first time. Moreover, it shows that organizations strive to fulfil promises and pay attention to the results. Reliability has been classed as the first dimension of the SERVQUAL service quality model. Studies by Lam (2002) ranked reliability as first in the dimensions of the service quality model. Reliability, a service quality component, is usually seen as a core aspect for service firms and if utilized well, customer retention is a guarantee. Reliability helps in building a healthy customer relationship that contributes to customer base growing because of referrals. Kersten and Koch (2010) emphasized how reliability component contributes to firm performance through time delivery, solving customer problems, doing right the first time and delivering damage-free goods. This component, therefore, cannot be ignored by entrepreneurial SACCOs who are keen on enhancing their performance through customer experience.

Yarimoglu (2014) defines access as approachability and ease of contact - the service is easily accessible by telephone, the waiting time to receive the service is not extensive, there are convenient hours of operation, and the service facility is in a convenient location. Access means the ease and convenience with which customers can use the services that banks offer. Approachability and ease of contact are the two most important elements of accessibility. Research has shown that greater accessibility to services results in increased customer satisfaction (Flavian, Torres, \& Guinaliu, 2004). As one of the dimensions of service image, accessibility may have a significant direct or indirect influence on a SACCO's customer satisfaction and loyalty (Ladhari, Souiden, \& Ladhari, 2011).

Olorunniwo and Hsu (2006) in their study of "A Typology Analysis of Service Quality, Customer Satisfaction and Behavioural Intentions in Mass Services" established that, accessibility" a service quality dimension, significantly contributes to firm performance since the customers are able to access the services they require with ease and at their convenience. Accessibility of SACCO services by customers at their own pace without any hindrances makes them customer centric in the way they are managing their processes.

Security of information, another Service Quality Practice dimension, is key for customer-oriented SACCOs that are keen on growing their customer base. Customers would develop confidence with how their transactions are being managed by SACCOs if they get to know that, the SACCO employees are observing a code of conduct when handling customers' information. These service quality practices, (especially accessibility and security of information) are important in accelerating the adoption rate of online services such as internet banking which is a key enhancer of firm performance (Raviadaran, Dastane, Ma'arif, \& Satar, 2019). Customers will use internet banking more often if they feel that SACCOs have put stringent measure that protects their data from hackers. Even if some information is lost, the Process Innovation Promoters should be in a position to retrieve the data and explain to the clients what had happened and assure them it won't happen again. This kind of customer relationship management retains current customers and it also attracts new customers hence the SACCO improving on its performance.

Technology-based self- service has greatly changed the way that service firms and consumers interact in providing consumers with a superior experience with respect to the interactive flow of information and security of the service. Entrepreneurial SACCOs that have entrepreneurial culture cannot ignore service quality practices in their day to day operations.

Co-operative Societies being financial institutions must offer reliable, accessible and secure services to their clientele and this can only be achieved by integrating the technological innovations in the operations of these collective enterprises (SACCOs).

This study concludes that, a Service quality model comprising of process innovation promoters, service quality practices and performance is a sure way of enhancing collective entrepreneurship. Having entrepreneurial SACCOs in Kenya, will reduce poverty levels amongst Kenyans who rely on them in growing their asset base. 
Co-operative Societies which have incorporated in its processes, new ideas and service quality practices including reliability, accessibility and security of information all the time will deliver on their mandate which is service provision. An innovative SACCO will be competitive in-service provision. This is in line with the Abernathy and Utterback (1978) model where competitive environment and organizational structure were all interacting and closely linked and they found out that, the institution innovation will pass through phases, each of them impacting differently on performance. Cooperative societies in Kenya that purposely qualify an employee as a Process Innovation Promoter are assured of process and service innovations that will enhance customer experience and therefore the co-operative institutions should remain customer centric. The Service Quality Practices when exercised in the normal SACCOs' operations improve the service provisions and since this is the major source of revenue to the SACCOs, the performance also improves. Thus, the study concludes that Service Quality Practices moderate the relationship between Process Innovation Promoters and performance of SACCOs in Kenya.

The study therefore recommends that, the cooperative societies in Kenya need to invest more on an effective innovation process that will enable process innovation promoters to embrace service quality practices that will ensure positive performance. Co-operative societies customers would like to deal with employees who make them have memorable experiences and will remain customer focused and customer centric. Co-operative societies in Kenya should think of modernising their processes and incorporating service quality practices components in their management model. The study also recommends that, SACCOs in Kenya need to introduce training sessions that will develop an entrepreneurial employee who can easily graduate to be a Process Innovation Promoter. Environmental dynamism makes a SACCO realise that; it has to invest in Service Quality Practices that will help it drive the market.

This study also fills the gaps identified at the literature review stage where it had shown that not much had been researched on the moderating effect of Service Quality Practices on the relationship between Process Innovation Promoters and Performance of SACCOs in Kenya.

\section{References}

Ahmad, K. (2014). The adoption of Management accounting practices in Malaysian Small and Medium-sized Enterprises. Asian Social Science, 10 (2), pp. 236-249.

Baumgartner, H., \& Hombur, C. (2006). Applications of Structural Equation Modeling in Marketing and Consumer Research: A review. International Journal of Research in Marketing, 13, 139-161.

Browne, M. W., \& Cudeck, R. (2009). Single Sample Cross-Validation Indices for Covariance Structures. Multivariate Behavioural Research. 24, 445-455.

Camp, W. G. (2001). Formulating and Evaluating Theoretical Frameworks for Career and Technical Education Research. Journal of Vocational Educational Research, 26 (1), 27-39.

Cebeci, C. \& Kol, E. (2013).Analysis for the Implementation of the Business Process Management in Selected Turkish Enterprises. Journal of Economics and Financial Issues Vol. 3, No. 2, 2013, pp.420-425 ISSN: 2146-4138

Chin, C.H, Lo. M.C \& Ramayah, T. (2013). Market Orientation and Organizational Performance: The Moderating Role of Service Quality. SAGE Open, pp 1-14.

Erkmen, E. (2018). Managing Your Brand for Employees: Understanding the Role of Organizational Processes in Cultivating Employee Brand Equity. Administrative Sciences. https:// doi.org/10.3390/admsci8030052

Flavian, C., Torres, E. \&Guinaliu, M. (2004).Corporate image measurement: A further problem for the tangibilization of Internet banking services. International Journal of Banking and Marketing, 22, 366-384.

Fogli, L. (2006). Customer Service Delivery. San Francisco: Jossey-Bass.

Folan, P. and Browne, J. (2005). A Review of Performance Measurement: Towards Performance Management, Computers in Industry, Vol. 56, pp 663 -680.

Gemünden, H.G., Salomo, S. \& Holzle, K. (2007). Role models for radical innovations in times of open innovation. Creativity and Innovation Management, Vol. 16 No. 4, pp. 408-421.

Goduscheit, R. C. (2014). A Revision of the Role of Innovation Promoters: Towards a Dynamic Approach. Technology \& Innovation Management. Academy of Management Proceedings

Gunday, G., Ulusoy, G., Kilic, K. \& Alpkan, L. (2011). Effects of innovation types on firm performance. International Journal of Production Economics, 133(2), 662-676. doi: 10.1016/j.ijpe.2011.05.014

Hair, J. F., Black, W. C., Babin. B. J., \& Anderson, R. E. (2010). Multivariate Data Analysis (5th Ed.). New Jersey: Pearson Prentice Hall.

Hauschildt, J. (2004). Innovations management, München: Vahlen.

Hauschildt, J. \& Schewe, G. (1997). Gatekeeper und Promotoren. Schlüsselpersonenin Innovationsprozessen in statischer und dynamischerPerspektive, Die Betriebswirtschaft57, 506-516. 
Hauschildt, Jürgen \&Chakrabarti, A. K. (1988), Arbeitsteilungim Innovations management - Forschungsergebnisse, Kriterien und Modelle, Zeitschriftfür Organisation 57, 378-388.

Hauschildt, J. \& Kirchmann, E. (1997).ArbeitsteilungimInnovationsmanagement. ZurExistenz und Effizienz von Prozesspromotoren, ZeitschriftFührung und Organisation 66, 68-73.

He, H. \& Li, Y. (2011). CSR and Service Brand: The Mediating Effect of Brand Identification and Moderating Effect of Service Quality. Journal of Business Ethics (2011) 100:673-688 _ Springer 2010.DOI 10.1007/s10551-0100703-y

Hu, L. T.\& Bentler, P. M. (1999). Evaluating Model Fit. Structural Equation Modeling: Concepts, Issues, and Applications. Thousand Oaks, CA: Sage.

Khantimirov, D. (2017). Market Share as a Measure of Performance: Conceptual Issues and Financial Accountability for Marketing Activities within a Firm. Journal of Research in Marketing. Volume 7 No.3 August 2017

Kombo, F. (2015). Customer satisfaction in the Kenyan banking industry. Journal of International Studies, Vol. 8, No 2, 2015, pp. 174-186. DOI: 10.14254/2071-8330.2015/8-2/15

Koskinen, K.U. (2012). Knowledge integration in systems integrator type project-based companies: a systemic view. International Journal of Managing Projects in Business, Vol. 5 No. 2, pp. 285-299.

Ladhari, R., Souiden, N. \& Ladhari, I. (2011). Determinants of loyalty and recommendation: The role of perceived service quality, emotional satisfaction and image. Journal of Finance and Service Marketing. 16, 111-124.

Lam, T.K. (2002). Making sense of SERVQUAL's dimensions to the Chinese customers in Macau. Journal of Market Focused Management. 2002, 5, 43-58.

Marsh, H.W., Balla, J.R., \& McDonald, R.P. (2011). Goodness-of-fit Indexes in Confirmatory Factor Analysis: The Effect of Sample Size. Psychological Bulletin 103 (3), 391-410.

McDonald, R. P. \& Ho, M. R. (2002). Principles and practice in reporting structural equation analyses. Psychological Methods, 7, 64-82

OECD Oslo Manual (2005).The Measurement of Scientific and Technological Activities.

Parasuraman, A., Zeithaml, V.A. \& Berry, L.L. (1994). Reassessment of expectations as a comparison standard on measuring service quality: Implications for further research. Journal of Marketing.1994, 58, 111-124.

Peshkin, A. (1993). The Goodness of Qualitative Research. Educational Researcher, 22(2), 23-29

Premkumar, B. (2018). Conceptual Frameworks/Models/Theories in Research Related to Women's Studies: An Application in Girls' /Women Health Focusing on Empowering Sexual Health and Safety - Education. IOSR Journal of Nursing and Health Science (IOSR-JNHS) e-ISSN: 2320-1959.p- ISSN: 2320-1940Ｖol. 7, Issue 6 Ver. VI. (Nov.-Dec.2018), PP 47-58

Rost, K., Hölzle, K \& Gemünden, H., G. (2007). Promoters or Champions? Pros and Cons of Role Specialization for Economic Process. Schmalenbach Business Review, 59,340-363

Ryynänen, H. \& Salminen, R.T. (2014).Promoters in a matrix organization's social network during industrial project sales. International Journal of Managing Projects in Business, Vol.7 Iss 4 pp. 701-719: http://dx.doi.org/10.1108/IJMPB-11-2013-0066

Saghier, N. M. E (2015). Managing Service Quality: Dimensions of service quality. International Journal of African and Asian Studies, Vol.9, 2015.ISSN 2409-6938

Sembiring, R. (2016). Impact of Human Resources' Knowledge and Skills on SMEs in Medan City, Indonesia. International Journal of Management, Economics and Social Sciences 2016, Vol.5 (3), pp. 95 - 104. ISSN 2304 $-1366$

Simon, V. T. \& Thomas, A. S. R. (2016). Effect of electronic banking on customer satisfaction in selected commercial banks, Kenya. International Academic Journal of Human Resource and Business Administration, 2 (2), 41-63

Sintset, K.G., Nekoumanesh, S \& Yang, M. (2013). Process Innovation: Impacts on Organization's Performance: A Qualitative Study of Four Swedish Municipalities. Linnaeus University, School of Business and Economics, Department of Marketing.

Taouab, O. \&Issor, Z. (2019). Firm Performance: Definition and Measurement Models. European Scientific Journal. Vol.15, No.1 ISSN: 1857 - 7881 (Print) e - ISSN 1857- 7431

URL: http://dx.doi.org/10.19044/esj.2019.v15n1p93

Vosloban, R. I. (2012). The Influence of the Employee's Performance on the company's growth - a managerial perspective. Procedia Economics and Finance 3 (2012) 660 -665

Yarimoglu, E.K. (2014). A review on dimensions of service quality models. Journal of Marketing Management. 2014, 2, 79-93.

Zhao, Y.L., \& Benedetto, C.A. D. (2013). Designing service quality to survive: empirical evidence from Chinese new ventures. Journal Business Research .66(8), 1098-1107.doi: 10.1016/j.jbusres.2012.03.006 
